\title{
The implications of microbial and substrate limitation for the fates of carbon in different organic soil horizon types of boreal forest ecosystems: a mechanistically based model analysis
}

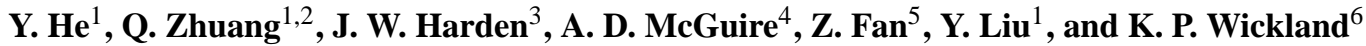 \\ ${ }^{1}$ Department of Earth, Atmospheric, and Planetary Sciences, Purdue University, West Lafayette, IN, USA \\ ${ }^{2}$ Department of Agronomy, Purdue University, West Lafayette, IN, USA \\ ${ }^{3}$ US Geological Survey, 345 Middlefield Rd, Menlo Park, MS 962, CA 94025, USA \\ ${ }^{4}$ US Geological Survey, Alaska Cooperative Fish and Wildlife Research Unit, University of Alaska Fairbanks, \\ Fairbanks, AK, USA \\ ${ }^{5}$ Argonne National Laboratory, Biosciences Division, 9700 South Cass Avenue, Argonne, IL 60439, USA \\ ${ }^{6}$ US Geological Survey, 3215 Marine Street, Boulder, CO 80303, USA
}

Correspondence to: Y. He (he72@purdue.edu)

Received: 29 December 2013 - Published in Biogeosciences Discuss.: 10 February 2014

Revised: 14 July 2014 - Accepted: 16 July 2014 - Published: 25 August 2014

\begin{abstract}
The large amount of soil carbon in boreal forest ecosystems has the potential to influence the climate system if released in large quantities in response to warming. Thus, there is a need to better understand and represent the environmental sensitivity of soil carbon decomposition. Most soil carbon decomposition models rely on empirical relationships omitting key biogeochemical mechanisms and their response to climate change is highly uncertain. In this study, we developed a multi-layer microbial explicit soil decomposition model framework for boreal forest ecosystems. A thorough sensitivity analysis was conducted to identify dominating biogeochemical processes and to highlight structural limitations. Our results indicate that substrate availability (limited by soil water diffusion and substrate quality) is likely to be a major constraint on soil decomposition in the fibrous horizon (40-60\% of soil organic carbon (SOC) pool size variation), while energy limited microbial activity in the amorphous horizon exerts a predominant control on soil decomposition ( $>70 \%$ of SOC pool size variation). Elevated temperature alleviated the energy constraint of microbial activity most notably in amorphous soils, whereas moisture only exhibited a marginal effect on dissolved substrate supply and microbial activity. Our study highlights the different decomposition properties and underlying mechanisms of soil dynamics between fibrous and amorphous soil horizons. Soil
\end{abstract}

decomposition models should consider explicitly representing different boreal soil horizons and soil-microbial interactions to better characterize biogeochemical processes in boreal forest ecosystems. A more comprehensive representation of critical biogeochemical mechanisms of soil moisture effects may be required to improve the performance of the soil model we analyzed in this study.

\section{Introduction}

Decomposition of the large stocks of soil organic matter in northern high latitude ecosystems in response to warming is one of the largest potential feedbacks to climate change (Bond-Lamberty and Thomson, 2010; Tarnocai et al., 2009). The already significant and expected to be more pronounced warming in the Arctic regions (ACIA, 2004) in conjunction with the large carbon (C) storage in northern permafrost soils (1104-1672 Pg, $50 \%$ of total global belowground organic C; Tarnocai et al., 2009, Hugelius et al., 2014) makes the understanding of how soil decomposition responds to warming climate in boreal regions an increasingly critical issue. Regional and global scale soil C models (e.g., earth system models) are often used to project future feedbacks between terrestrial ecosystem $\mathrm{C}$ cycle and climate. However, 
these models often predict a wide range of soil $\mathrm{C}$ response (Todd-Brown et al., 2013) and they omit key biogeochemical mechanisms based on empirical regression analyses (Conant et al., 2011; Schmidt et al., 2011). In contrast, recent mechanistically based models that explicitly account for microbial biomass pools and enzyme kinetics that catalyze soil $\mathrm{C}$ decomposition produce notably different results and provide a closer match to contemporary observations (Allison et al., 2010; Wieder et al., 2013).

Although microbial models exhibit great potential for better representation for decomposition dynamics, such models usually have many parameters and some are difficult to be directly determined by measurements (Manzoni 2014), thus the model can be poorly constrained when used in real applications. In contrast to parameter adjustments which can often compensate structural uncertainties and generate satisfactory model performance that matches well with observations (Beven, 2006; Bonan et al., 2011; Keenan et al., 2011; Medlyn et al., 2005), sensitivity analysis helps to identify the assumptions and parameters that have the most important weight in the modeling system. Such information can guide critical experimental work to inform the model (especially the most influential parameters) and help better constrain the model. Sensitivity analysis thus helps to understand the contribution of the various sources of uncertainty to the model output and also to quantify the relative importance of the assumptions, to highlight model limitations, and to provide direction for further modeling improvements as well as experimental efforts (Medlyn et al., 2005; Saltelli and Scott, 1997; Saltelli et al., 2000b). In addition, for soil decomposition models that explicitly represent microbial physiology, enzymatic activity, the direct effects of temperature and soil moisture on substrate diffusion and availability (Davidson et al., 2005; Schimel and Weintraub, 2003), and the heterogeneity of soil organic C (substrate quality and availability, and temperature sensitivity) (Davidson and Janssens, 2006; Knorr et al., 2005), we postulate that a thorough sensitivity analysis can reflect the sensitivity of the real processes and thus help to better understand the dynamics of decomposition and its dominating factors.

In this study, we developed a mechanistically based soil decomposition modeling framework based on a multi-layer soil vertical architecture in Yi et al. (2009) to represent soil $\mathrm{C}$ dynamics for boreal forest ecosystems. This framework incorporates the dual Arrhenius and Michaelis-Menten kinetics model proposed by Davidson et al. (2012) and the generic microbial-enzyme model of Allison et al. (2010) to explore the underlying mechanisms of soil respiration. This model framework is built upon the existing biochemical kinetics theory (Arrhenius and Michaelis-Menten type of functions), and explicitly represents the direct impact of temperature and moisture on biochemical reactions and the indirect effects on soil decomposition via substrate availability, enzyme activities and microbial physiology. We first calibrated the model against observed soil respiration data, we then con-

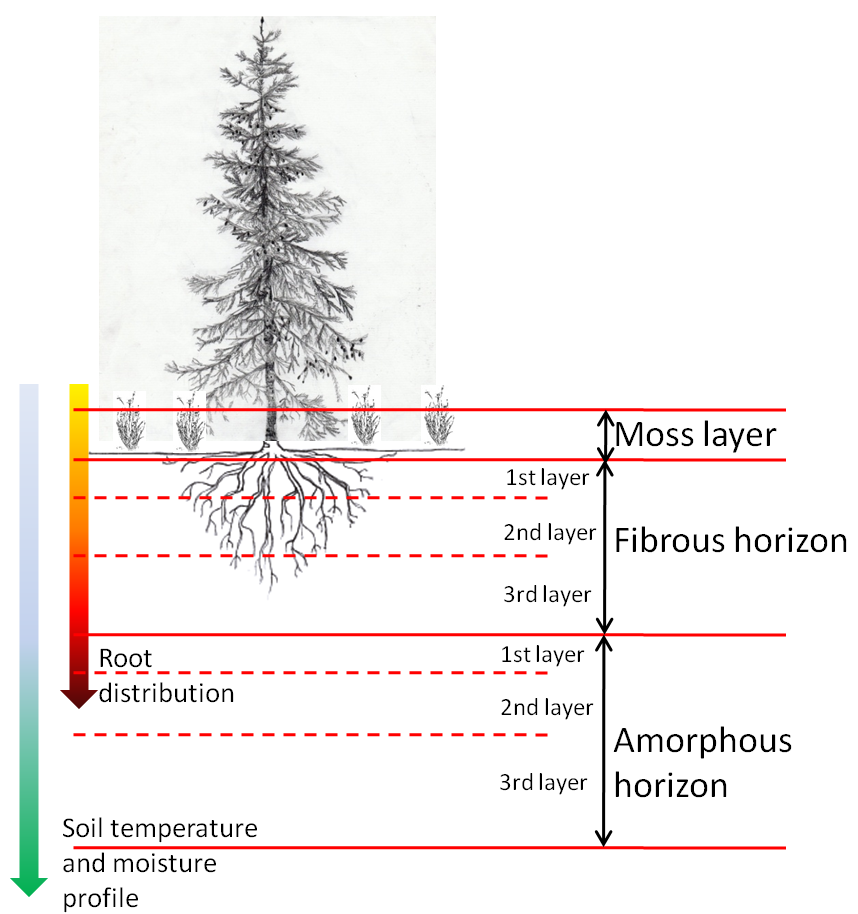

Figure 1. Schematic representation of the soil decomposition model.

ducted a sensitivity analysis to evaluate model limitations and gain heuristic understanding of the processes and mechanisms to further improve the model. Elevated temperature and altered moisture regimes were simulated to elucidate the impact of temperature and soil moisture on dominant decomposition processes. In particular, the following questions are addressed: (1) is this modeling framework able to reflect the sensitivity of the real processes? (2) What are the dominating parameters and processes in regulating soil $\mathrm{C}$ decomposition in fibrous and amorphous (fibric and humic in Canadian soil classifications, or Oi and Oa US soil classifications) organic soil horizons? (3) What are the most influential parameters or processes that need critical attention in experimental work? Specifically, the sensitivity analysis will help to evaluate (1) how well the model structure represents the real soil decomposition processes, (2) identify the factors that mostly contribute to the output variability (thus the processes where accurate parameterization is critical), and (3) the important interactions among factors in the model.

\section{Methods}

\subsection{Model description}

We simulate the soil using general organic horizon types to represent vertical soil heterogeneity in boreal ecosystems (Yi et al., 2009) (Fig. 1). The three soil horizon types are (1) live moss at the surface ("live"); (2) slightly decomposed, fibrous 
Table 1. Bulk density, carbon fraction, horizon thickness for different organic horizon types in soil profiles of black spruce stand in this study.

\begin{tabular}{llrrl}
\hline & & Fibrous & Amorphous & References \\
\hline \multirow{2}{*}{ Bulk density $\left(\mathrm{g} \mathrm{cm}^{-3}\right)$} & Mean & 0.06 & 0.28 & \multirow{2}{*}{ (Manies et al., 2004) } \\
& STD $(n)$ & $0.049(5)$ & $0.097(4)$ & \\
Carbon fraction $(\%)$ & Mean & 41.12 & 21.13 & (Manies et al., 2004) \\
& STD $(n)$ & $2.24(5)$ & $6.77(4)$ & \\
Particle density $\left(\mathrm{g} \mathrm{cm}^{-3}\right)$ & Mean & 1.33 & 1.33 & (Wickland and Neff, 2008) \\
& STD $(n)$ & - & - & \\
Horizon thickness $(\mathrm{cm})$ & Mean & 12 & 19.25 & (Manies et al., 2004) \\
& STD $(n)$ & $3.33(4)$ & $3.4(4)$ & \\
\hline
\end{tabular}

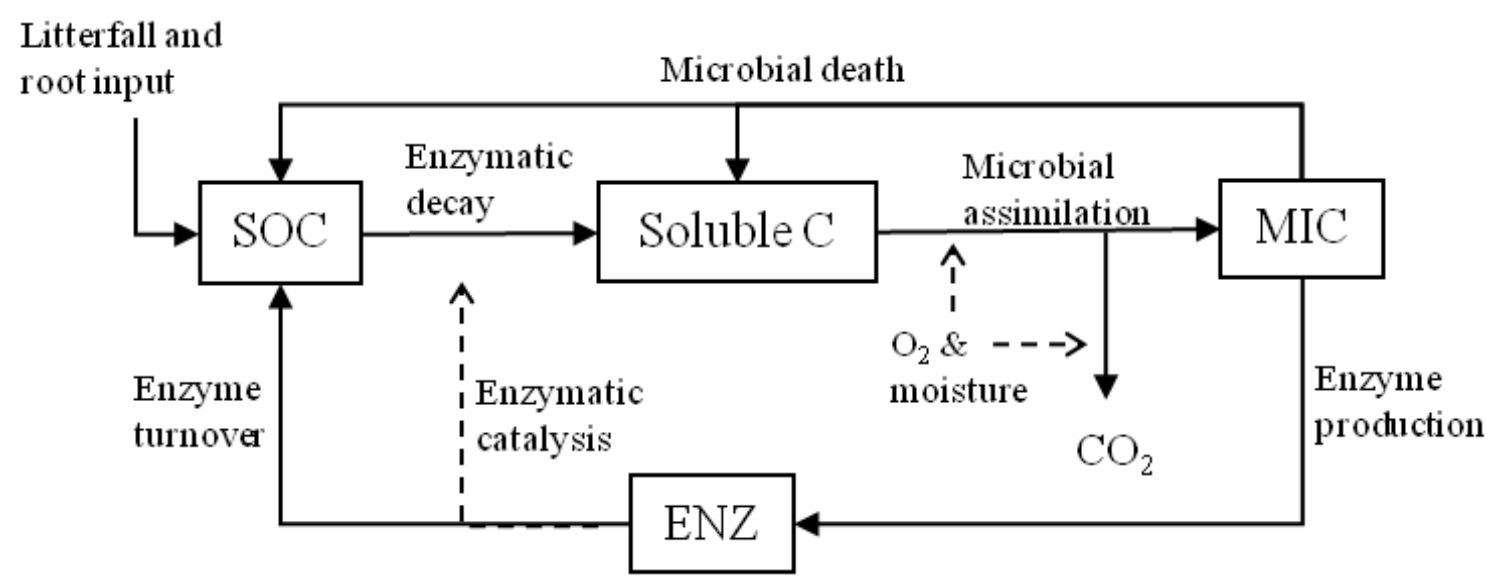

Figure 2. Conceptual representation of soil decomposition dynamic in each layer. Rectangles represent stocks; solid arrows denote C flows; dashed arrows represent other controls.

organic layer made up of both dead moss and live/dead roots ("fibrous"); and (3) moderately to highly decomposed amorphous organic material ("amorphous"). Note that in the study, only heterotrophic respiration (i.e., soil organic $\mathrm{C} \mathrm{min-}$ eralization in fibrous and amorphous horizons) is analyzed; autotrophic respiration from live roots is not presented. Fibrous and amorphous horizons are subdivided into a maximum of three layers each based on the total thickness of a soil organic horizon, similar to the structure of soil organic horizons in Yi et al. (2010). This architecture of layers is typical for boreal black spruce (Picea mariana (Mill.) Britton, Sterns and Poggenburg) forests, one of the major boreal forest ecosystem types in North America (Yarie, 2000). The model simulates soil $\mathrm{C}$ dynamics in organic layers up to $1 \mathrm{~m}$ in thickness. The thickness of a layer can be modified for application in other ecosystems. Temperature and moisture profiles are depth dependent variables needed for modeling soil $\mathrm{C}$ dynamics in each layer (see below). Each layer of fibrous and amorphous horizons consists of four $\mathrm{C}$ pools: soil organic $\mathrm{C}$ pool (SOC), soluble $\mathrm{C}$ pool (solubleC), microbial biomass $\mathrm{C}$ pool (MIC), and enzyme $\mathrm{C}$ pool (ENZ) (Fig. 2). Litterfall, as part of $\mathrm{C}$ input to the soil in addition to root exudates, is prescribed as a portion of net primary production (NPP) and contributes to the fibrous and amorphous horizon with 70 and $30 \%$, respectively (follows the fine root distribution of black spruce in Canadian boreal regions, Steele et al., 1997). Since only C is simulated, the model implicitly assumes a constant $\mathrm{C}: \mathrm{N}$ (Nitrogen) ratio for each pool in the system and the effect of changes in $\mathrm{N}$ limitation is not simulated. $\mathrm{C}$ transport and conversion between pools are simulated with Arrhenius/Michaelis-Menten type equations, except for enzyme production and turnover, which is modeled as a prescribed portion of the enzyme pool. The enzymatic decay of SOC where polymer breakdown into monomers, microbial assimilation of the dissolved organic $\mathrm{C}$, and microbial respiration are simulated as

$$
\begin{aligned}
& \text { DECAY }=V \max _{\mathrm{SOC}} \times \mathrm{Enz} \times \frac{\mathrm{SOC}}{\mathrm{kM}_{\mathrm{SOC}}+\mathrm{SOC}} \\
& \mathrm{ASSIM}=V \max _{\text {uptake }} \times \mathrm{MIC} \times \frac{\left[S_{x}\right]}{k \mathrm{M}_{\left[S_{x}\right]}+\left[S_{x}\right]} \\
& \mathrm{CO}_{2}=V \max _{\mathrm{CO}_{2}} \times \frac{\left[S_{x}\right]}{\mathrm{kM}_{\left[s_{x}\right]}+\left[S_{x}\right]} \times \frac{\left[\mathrm{O}_{2}\right]}{\mathrm{kM}_{\mathrm{O}_{2}}+\left[\mathrm{O}_{2}\right]} \times \mathrm{MIC},
\end{aligned}
$$

where $V$ max $\operatorname{soc}, V \max _{\text {uptake }}$, and $V \max _{\mathrm{CO}_{2}}$ are the maximum velocity of the corresponding reaction with a generic formula $V \max _{x}=V \max _{x_{0}} \times \exp \left(-\frac{\mathrm{Ea}_{x}}{\mathrm{R} \times(\operatorname{temp}+273)}\right)$ with $x$ denoting corresponding process. Ea is the activation energy 
for the specific reaction $\left(\mathrm{J} \mathrm{mol}^{-1}\right), R$ is the ideal gas constant (8.314 $\mathrm{J} \mathrm{mol}^{-1} \mathrm{~K}^{-1}$ ), and temp is the temperature in Celsius under which reaction occurs. $\mathrm{kM}$ (unit substrate $\mathrm{cm}^{-3}$ soil) is the corresponding Michaelis-Menten constant. The concentration of dissolved organic substrates at the reactive site of the enzyme ( $\left.\left[S_{x}\right]\right)$ is affected by soil water content, and specifically by diffusion of substrates through soil water films (Davidson et al., 2012). [ $\left.S_{x}\right]$ is calculated from [ $S_{x \text { soluble }}$ (total soluble C, i.e., Soluble C pool in the model) through $\left[S_{x}\right]=\left[S_{x}\right.$ soluble $] \times \mathrm{D}_{\text {liq }} \times \theta^{3}$, where $\theta$ is the volumetric water content of the soil and $D_{\text {liq }}$ is the diffusion coefficient of the substrate in liquid phase (Davidson et al., 2012).

The soil model runs on an hourly time step driven by soil moisture, soil temperature, and NPP. For detailed model description see supplementary material.

\subsection{Inverse parameter estimation and initial values}

We parameterized the model for a black spruce dominated forest ecosystem underlain by permafrost (soil or rock that remains at or below $0^{\circ} \mathrm{C}$ for 2 or more years at depths of about $40 \mathrm{~cm}$ ) in central Alaska (Donnelly Flats; lat $63^{\circ} 51^{\prime} \mathrm{N}$, long $145^{\circ} 42^{\prime} \mathrm{W}$ ) (Manies et al., 2004). Monthly soil temperature and moisture were recorded at depths of 5, 10, and $15 \mathrm{~cm}$ for soil temperature, and $6 \mathrm{~cm}$ for soil moisture (Wickland et al., 2010). The temperature and moisture profile below the above mentioned depth (up to $70 \mathrm{~cm}$ for soil temperature, $40 \mathrm{~cm}$ for soil moisture) were specified with data from Manies et al. (2003). Note here that for model sensitivity analysis purposes, we used the same monthly temperature and moisture for all the days within a month, therefore the diurnal variation of soil $\mathrm{C}$ dynamics are not reflected in the modeling results. Although the model does not explicitly simulate permafrost dynamics, the use of measured soil temperature and moisture content implicitly accounts for seasonal freeze/thaw and their physical controls on soil decomposition (e.g., the moisture limitation imposed by permanently frozen horizons). However, we acknowledge that the seasonal freeze-thaw processes and ground ice may have a great impact on microbial activity (see Sect. 4.2 in Discussion), which is not represented in the model. Site-level monthly NPP used in the model is specified based on Fan et al. (2008) who used data from Mack et al. (2008), where the total annual NPP (aboveground as in stem, branch, and moss; plus belowground as in root) is $250 \mathrm{~g} \mathrm{C} \mathrm{m}^{-2} \mathrm{yr}^{-1}$. Average bulk density, $\mathrm{C}$ fraction, and horizon thickness at the black spruce site were determined based on Maines et al. (2004) (Table 1). The initial pool size for MIC, SolubleC and ENZ are prescribed according to the proportion used in Allison et al. (2010). Other SOC and microbial activity specific parameters are determined based on other studies (Table 2).

We used a global optimization algorithm (Shuffled complex evolution method developed at the University of Arizona, Duan et al., 1992, 1994) to constrain the poorly documented Vmax-related parameters of fibrous and amorphous horizons (Vmax_uptake0, Vmax_CO20 and Vmax SOC0). The global optimization method is used to seek the minimum of a cost function defined by the sum of squared residuals:

Obj $=W_{\text {resp }} \times \sum_{i=1}^{k}\left(\operatorname{Resp}_{\text {obs }, i}-\operatorname{Resp}_{\text {sim }, i}\right)^{2}+W_{\text {mic } / \mathrm{soc}}$

$\times \sum_{i=1}^{k}\left(\frac{\mathrm{MIC}_{\mathrm{sim}, i}}{\mathrm{SOC}_{\mathrm{sim}, i}}-0.02\right)^{2}+W_{\text {cue }}$

$\times \sum_{i=1}^{k}\left(\mathrm{CUE}_{\mathrm{sim}, i}-0.4\right)^{2}$,

where the simulated soil respiration is matched with observation $\left(\operatorname{Resp}_{\mathrm{sim}}, \mathrm{Resp}_{\mathrm{obs}}\right)$, the ratio between MIC pool and SOC pool is assumed to fluctuate around $2 \%$, and simulated carbon use efficiency (CUE; $1-\mathrm{CO}_{2}$ / assimilation; for details see supplementary material) should fluctuate around 0.4 (consider potential low quality substrates in boreal forest soils; Frey et al., 2013; Manzoni et al., 2012; Sinsabaugh et al., 2013). $W_{\text {resp }}, W_{\text {mic/soc }}$, and $W_{\text {cue }}$ are the weighting function set to $6.0 \times 10^{6}, 1000$ and 100 , respectively, to reconcile the different magnitudes of metrics with approximately equal weight on $\mathrm{MIC} / \mathrm{SOC}$ ratio and CUE, and a higher weight on respiration. $k$ is the number of data pairs available to compare observation and simulation. The chamber measured monthly soil respiration data during 2003 (March-October) at the black spruce site (Wickland et al., 2010) were used for the inverse modeling. In all, $50 \%$ of the measured total soil respiration was assumed to be heterotrophic respiration (Schuur and Trumbore, 2006; Wang et al., 2002). The minimized cost function featured an adjusted $R^{2}$ of 0.89 and slope of $1.19(p<0.05)$ for simulated and observed heterotrophic soil respiration (Fig. 3). The inverse parameters together with other parameters (Table 2) were then used in the global sensitivity analysis.

\subsection{Model experimental design}

We performed a global model sensitivity analysis of recorded annual temperature and moisture conditions at the black spruce site in 2003 on decomposition parameters. Hereafter we refer to 2003 conditions as standard. Permafrost degradation under warmer climate can lead to complex hydrological consequences with wetter or drier soil condition depending on local microtopography, hydrology, ice content, vegetation, and other factors, (Jorgenson and Osterkamp, 2005; O'Donnell et al., 2012). To test how the sensitivity of decomposition parameters may change under warmer climate and the complex moisture conditions, we also set up three scenarios for sensitivity tests: (1) elevated temperature and standard moisture, (2) elevated temperature and raised moisture, and (3) elevated temperature and lowered moisture. We raised the monthly average temperature by $3{ }^{\circ} \mathrm{C}$ as the scenario of the elevated temperature, and moisture is varied by $30 \%$ around the standard value to account for the raised and 
Table 2. Parameters used in the model. Inverse estimates of specific parameters and parameter range used are listed. Bolded variables are the 10 selected parameters based on the Morris elementary effect test.

\begin{tabular}{|c|c|c|c|c|c|c|}
\hline Process & Parameter & Unit & Initial value & Description & Parameter range & References \\
\hline \multirow[t]{9}{*}{ Assimilation } & Ea_micup & $\mathrm{J} \mathrm{mol}^{-1}$ & 47000 & Soluble and diffused $S_{x}$ uptake by microbial & - & Allison et al. (2010) \\
\hline & Vmax_uptake0_f & $\begin{array}{l}\operatorname{mg~} S_{x} \mathrm{~cm}^{-3} \text { soil }(\mathrm{mg} \\
\text { biomass } \mathrm{cm}^{-3} \text { soil }^{-1} \mathrm{~h}^{-1}\end{array}$ & $9.97 \mathrm{e} 6$ & Maximum microbial uptake rate in fibrous horizon & {$[1.0 \mathrm{e} 4,1.0 \mathrm{e} 8]$} & - \\
\hline & Vmax_uptake0_h & $\begin{array}{l}\mathrm{mg} S_{x} \mathrm{~cm}^{-3} \text { soil }(\mathrm{mg} \\
\left.\text { biomass cm } \mathrm{cm}^{-3} \text { soil) }\right)^{-1} \mathrm{~h}^{-1}\end{array}$ & $5.26 \mathrm{e} 6$ & Maximum microbial uptake rate in amorphous horizon & {$[1.0 \mathrm{e} 4,1.0 \mathrm{e} 8]$} & - \\
\hline & c_uptake & $\mathrm{mg} S_{x} \mathrm{~cm}^{-3}$ soil & 0.1 & $\begin{array}{l}\text { Temperature regulator of MM for } S_{x} \text { uptake by microbes } \\
\text { (kM_uptake) }\end{array}$ & - & Allison et al. (2010) \\
\hline & m_uptake & $\mathrm{mg} S_{x} \mathrm{~cm}^{-3}$ soil $^{\circ} \mathrm{C}^{-1}$ & 0.01 & $\begin{array}{l}\text { Temperature regulator of MM for } S_{x} \text { uptake by microbes } \\
\text { (kM_uptake) }\end{array}$ & - & Allison et al. (2010) \\
\hline & Ea_Sx_f & $\mathrm{J} \mathrm{mol}^{-1}$ & 48092 & $\begin{array}{l}\text { Activation energy of microbes assimilating } S_{x} \text { to } \mathrm{CO}_{2} \text { in fi- } \\
\text { brous horizon }\end{array}$ & - & Knorr et al. (2005) \\
\hline & Ea_Sx_h & $\mathrm{J} \mathrm{mol}^{-1}$ & 64334 & $\begin{array}{l}\text { Activation energy of microbes assimilating } S_{x} \text { to } \mathrm{CO}_{2} \text { in } \\
\text { amorphous horizon }\end{array}$ & - & Knorr et al. (2005) \\
\hline & c_S $\mathrm{Sx}^{*}$ & $\begin{array}{l}\mathrm{mg} \text { assimilated } S_{x} \mathrm{~cm}^{-3} \\
\text { soil }\end{array}$ & 0.1 & $\begin{array}{l}\text { Temperature regulator of MM for microbial assimilation of } \\
S_{x}\left(\mathrm{kM} \_\mathrm{Sx}\right)\end{array}$ & - & Allison et al. (2010) \\
\hline & $\mathrm{m} \_\mathrm{Sx}^{*}$ & $\begin{array}{l}\text { mg assimilated } S_{x} \mathrm{~cm}^{-3} \\
\text { soil }{ }^{\circ} \mathrm{C}^{-1}\end{array}$ & 0.01 & $\begin{array}{l}\text { Temperature regulator of MM for microbial assimilation of } \\
S_{x}\left(\mathrm{kM} \_\mathrm{Sx}\right)\end{array}$ & - & Allison et al. (2010) \\
\hline \multirow[t]{7}{*}{ Decay } & Ea_SOC_f & $\mathrm{J} \mathrm{mol}^{-1}$ & 41000 & $\begin{array}{l}\text { Activation energy of decomposing SOC to soluble } \mathrm{C} \text { in fi- } \\
\text { brous horizon }\end{array}$ & - & $\begin{array}{l}\text { Modified from } \\
\text { Davidson et al. (2012) }\end{array}$ \\
\hline & Ea_SOC_h & $\mathrm{J} \mathrm{mol}^{-1}$ & 58000 & $\begin{array}{l}\text { Activation energy of decomposing SOC to soluble } \mathrm{C} \text { in amor- } \\
\text { phous horizon }\end{array}$ & - & $\begin{array}{l}\text { Modified from } \\
\text { Davidson et al. (2012) }\end{array}$ \\
\hline & Vmax_SOC0_f & $\begin{array}{l}\mathrm{mg} \text { decomposed SOC } \mathrm{cm}^{-3} \text { soil } \\
\left(\mathrm{mgEnzcm} \mathrm{cm}^{-3} \mathrm{soil}^{-1} \mathrm{~h}^{-1}\right.\end{array}$ & $9.17 \mathrm{e} 7$ & $\begin{array}{l}\text { Maximum rate of converting SOC to soluble } \mathrm{C} \text { in fibrous hori- } \\
\text { zon }\end{array}$ & {$[1.0 \mathrm{e} 5,1.0 \mathrm{e} 8]$} & - \\
\hline & Vmax_SOC0_h & $\begin{array}{l}\mathrm{mg} \text { decomposed } \mathrm{SOC} \mathrm{cm}^{-3} \text { soil } \\
\left(\mathrm{mgEnzcm} \mathrm{cm}^{-3} \text { soil }\right)^{-1} \mathrm{~h}^{-1}\end{array}$ & $3.76 \mathrm{e} 7$ & $\begin{array}{l}\text { Maximum rate of converting SOC to soluble } \mathrm{C} \text { in amorphous } \\
\text { horizon }\end{array}$ & {$[1.0 \mathrm{e} 5,1.0 \mathrm{e} 8]$} & - \\
\hline & c_SOC & $\mathrm{mg} \mathrm{SOC} \mathrm{cm}^{-3}$ soil & 400 & $\begin{array}{l}\text { Temperature regulator of MM for enzymatic decay of SOC to } \\
\text { soluble C (kM_SOC) }\end{array}$ & - & Allison et al. (2010) \\
\hline & $\mathrm{m} \_\mathrm{SOC}$ & $\mathrm{mg} \mathrm{SOC} \mathrm{cm}{ }^{-3}$ soil $^{\circ} \mathrm{C}^{-1}$ & 5 & $\begin{array}{l}\text { Temperature regulator of MM for enzymatic decay of SOC to } \\
\text { soluble C (KM_SOC) }\end{array}$ & - & Allison et al. (2010) \\
\hline & kM_O2 & $\mathrm{cm}^{3} \mathrm{O}_{2} \mathrm{~cm}^{-3}$ soil & 0.121 & $\begin{array}{l}\text { Michaelis-Menten constant (MM) for } \mathrm{O}_{2} \text { (at mean value of } \\
\text { volumetric soil moisture) }\end{array}$ & - & Davidson et al. (2012) \\
\hline \multirow[t]{4}{*}{$\mathrm{CO}_{2}$ production } & Vmax_CO20_f & mg respired $S_{x} \mathrm{~cm}^{-3}$ soil $\mathrm{h}^{-1}$ & $1.9 \mathrm{e} 7$ & Maximum microbial respiration rate in fibrous horizon & {$[1.0 \mathrm{e} 6,1.0 \mathrm{e} 8]$} & - \\
\hline & Vmax_CO20_h & mg respired $S_{x} \mathrm{~cm}^{-3}$ soil $\mathrm{h}^{-1}$ & $6.4 \mathrm{e} 7$ & Maximum microbial respiration rate in amorphous horizon & {$[1.0 \mathrm{e} 6,1.0 \mathrm{e} 8]$} & - \\
\hline & c_S $\mathrm{Sx}^{*}$ & $\mathrm{mg}$ assimilated $S_{x} \mathrm{~cm}^{-3}$ soil & 0.1 & $\begin{array}{l}\text { Temperature regulator of MM for microbial respiration of as- } \\
\text { similated } S_{x}\left(\mathrm{kM} \_\mathrm{Sx}\right)\end{array}$ & - & Allison et al. (2010) \\
\hline & $\mathrm{m} \_\mathrm{S} x^{*}$ & $\begin{array}{l}\text { mg assimilated } S_{x} \mathrm{~cm}^{-3} \\
\text { soil }{ }^{\circ} \mathrm{C}^{-1}\end{array}$ & 0.01 & $\begin{array}{l}\text { Temperature regulator of MM for microbial respiration of as- } \\
\text { similated } S_{x}\left(\mathrm{kM} \_\mathrm{Sx}\right)\end{array}$ & - & Allison et al. (2010) \\
\hline C input & Litter_NPPfrac & $\%$ & 30 & Fraction of NPP allocated to litterfall & - & Fan et al. (2008) \\
\hline \multirow[t]{2}{*}{ MIC turnover } & MICtoSOC & $\%$ & 50 & $\begin{array}{l}\text { Partition coefficient for dead microbial biomass between the } \\
\text { SOC and Soluble C pool }\end{array}$ & - & Allison et al. (2010) \\
\hline & r_death & $\% \mathrm{~h}^{-1}$ & 0.02 & Microbial death fraction & - & Allison et al. (2010) \\
\hline \multirow[t]{2}{*}{ ENZ turnover } & r_EnzProd & $\% \mathrm{~h}^{-1}$ & $5.0 \mathrm{e}-4$ & Enzyme production fraction & - & Allison et al. (2010) \\
\hline & r_EnzLoss & $\% \mathrm{~h}^{-1}$ & 0.1 & Enzyme loss fraction & - & Allison et al. (2010) \\
\hline
\end{tabular}

* c_S $\mathrm{S}$ and $\mathrm{m} \_\mathrm{Sx}$ are used in both assimilation and $\mathrm{CO}_{2}$ production calculations.

lowered moisture scenarios. Such temperature and moisture perturbations are based on observed thermokarst features in interior Alaska (O’Donnell et al., 2012).

\subsection{Model sensitivity analysis}

In the sensitivity analysis, we ran the model for 5 years with the output as time series of annual pool sizes for SOC, MIC, Soluble C, and ENZ. The pool sizes from each layer (three layers total for each horizon) in fibrous and amorphous horizons are summed up, respectively, as our output of interest representing the four pools in fibrous and amorphous soils. We first implemented a screening test (Sect. 2.4.1) over the total 23 parameters (Table 2) to identify the most important parameters at low computational cost; a quantitative, explicit evaluation (sECT. 2.4.2) of the importance and interactions among the selected 10 parameters (bolded in Table 2) was then performed to provide detailed sensitivity analysis over those most influential parameters. The theoretical basis for the need of screening test is the Pareto principle (also known as the $80-20$ rule), that is, $80 \%$ of the variation in model outputs can be attributed to $20 \%$ of all parameters (Saltelli et al., 2000a). The identification of the few influential parameters and the noninfluential ones can help reduce the uncertainty and computational load for more explicit and computationally expensive variance-based sensitivity analysis.

A more detailed description of the theoretical background for the sensitivity analysis methods used in this study can be found in Pappas et al. (2013). Below we briefly outlined the steps we took in this study.

\subsubsection{Elementary effects analysis}

The Morris (1991) elementary effects (EE) method for global sensitivity analysis is categorized as a one step at a time method, meaning that in each model run, only one input parameter is given a new value while other parameters remain the same. It is a full factorial sensitivity analysis of all calibrated parameters. An analysis of variance was used to determine the significance of each parameter on the variance 


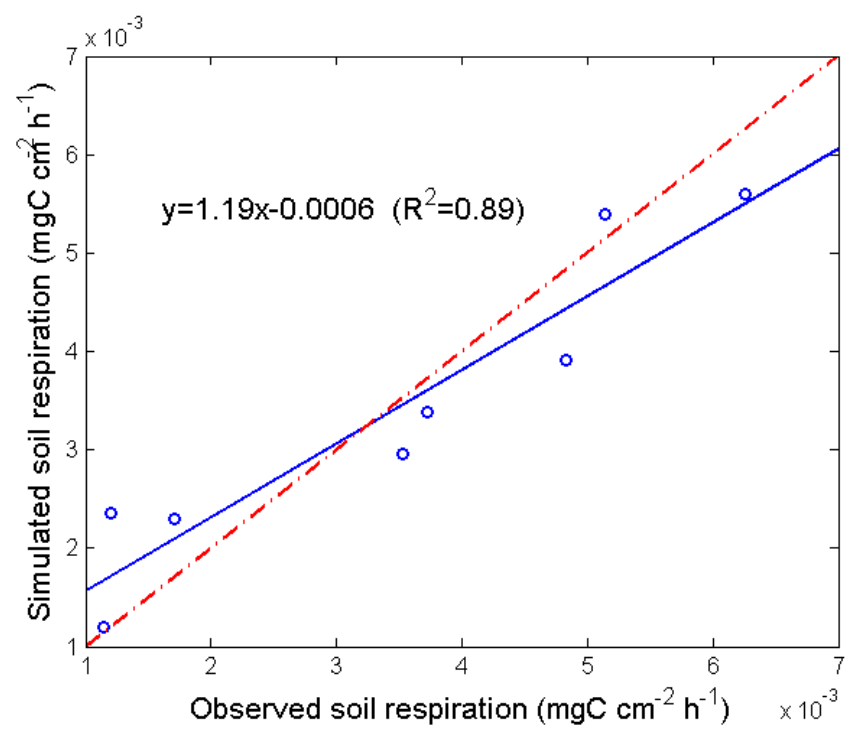

Figure 3. Simulated versus observed soil heterotrophic respiration from chamber measured monthly soil respiration during MarchOctober 2003 in a black spruce dominated forest site in central Alaska. Model parameters were estimated using inverse modeling to match modeled soil heterotrophic respiration with observations.

of model outputs of interest. The Euclidian distance from origin $(0,0)$ of the basic statistics $\left(\varepsilon=\sqrt{\mu_{\mathrm{EE}^{2}}^{*}+\sigma_{\mathrm{EE}^{2}}}\right.$, where $\mu_{\mathrm{EE}}^{*}$ is the absolute value of mean $\mu_{\mathrm{EE}}$ and $\sigma_{\mathrm{EE}}$ is standard deviation of incremental ratios from each model run) is calculated as a robust sensitivity metric (Campolongo et al., 2007). While the EE method can provide the relative importance of a given parameter over others in one sensitivity test, its sensitivity measure cannot be compared between sensitivity tests of different outputs due to its qualitative characters (e.g., a parameter scoring 0.5 on ENZ sensitivity test is not necessarily less influential than the same parameter scoring 5 on SOC sensitivity test), and it cannot quantify the interactions among parameters (Saltelli et al., 2000b, 2004). The altered temperature and soil moisture model experiment design were also implemented on the screening test to elucidate the impact of abiotic factors on soil $\mathrm{C}$ dynamics. For each sensitivity test with certain model output of interest, 100 uniformly distributed parameter samples were selected from 1000 repetitions of experiment design via spacefilling improvement (Campolongo et al., 2007) and a total of $100 \times(23+1)=2400$ model runs were conducted. To maximize the sensitivity difference among parameters, the parameters were generated with $50 \%$ variation around their original values; 10 out of 23 parameters were selected as more important parameters for the relatively computationally expensive variance-based sensitivity test.

\subsubsection{Variance-based sensitivity analysis}

We applied the Quasi-Monte Carlo estimation of Sobol's indices (Saltelli et al., 2010; Sobol et al., 2007) on parameter samples generated from low-discrepancy Sobol sequence. The parameters were designed to vary by $20 \%$ around original values to reduce the uncertainty introduced by overestimated parameter range. The Sobol indices consist of two indices: (1) the first-order sensitivity index (i.e., main effect index) representing the contribution to the output variance of the main effect (the effect of varying the parameter $X_{i}$ alone) of a specific parameter; and (2) the total-order sensitivity index which accounts for not only first- but also higherorder effects in a sense that it measures the contribution to the output variance of the parameter $X_{i}$, including all variance caused by the interactions between $X_{i}$ and any other parameter/parameters.

The model was developed in $\mathrm{C}++$ with ordinary differential equation solved using Runge-Kutta-Fehlberg 4(5) method. A portable implementation of the message passing interface, MPICH2 (1.4.1p1 with Intel 12.0.084 compiler) was used for parallel computing of parameter sweep to reduce computational cost. The sensitivity analysis was performed in the R statistical system (http://www.r-project. org). The inverse estimation of model parameters was conducted using the MATLAB optimization toolbox (Mathworks, 2012a). Any use of trade, firm, or product names is for descriptive purposes only and does not imply endorsement by the US Government.

\section{Results}

\subsection{Morris elementary effect test}

Fibrous and amorphous horizons are controlled by different parameters, and thus by different processes. Microbial biomass (MIC) in the fibrous horizon is most sensitive to parameters associated with solubilization, or the process of degrading SOC to soluble C (Ea_SOC_f and Vmax_SOC0_f, Fig. 4a), likely due to the low water holding capacity/higher porosity. MIC in the fibrous horizon is also highly sensitive to the activation energy of microbial assimilation (Ea_micup) and the external C input from litterfall (litter_NPPfrac), followed by enzyme kinetics-related parameters and the turnover of dead microbes to the SOC pool (MICtoSOC) (Fig. 4a). MIC in the amorphous horizon is generally dominated by the same set of parameters controlling fibrous $\mathrm{C}$ dynamics, with the exception that microbial assimilation (Ea_micup) exerts a much higher control in amorphous soil while solubilization (Ea_SOC_h) is not as influential as in fibrous soil (Fig. 4a). SOC generally resembled the sensitivity pattern of MIC except that SOC in the fibrous horizon is more sensitive to the external organic matter input (Litter_NPPfrac) (Fig. 4b). Soluble C in the fibrous horizon 

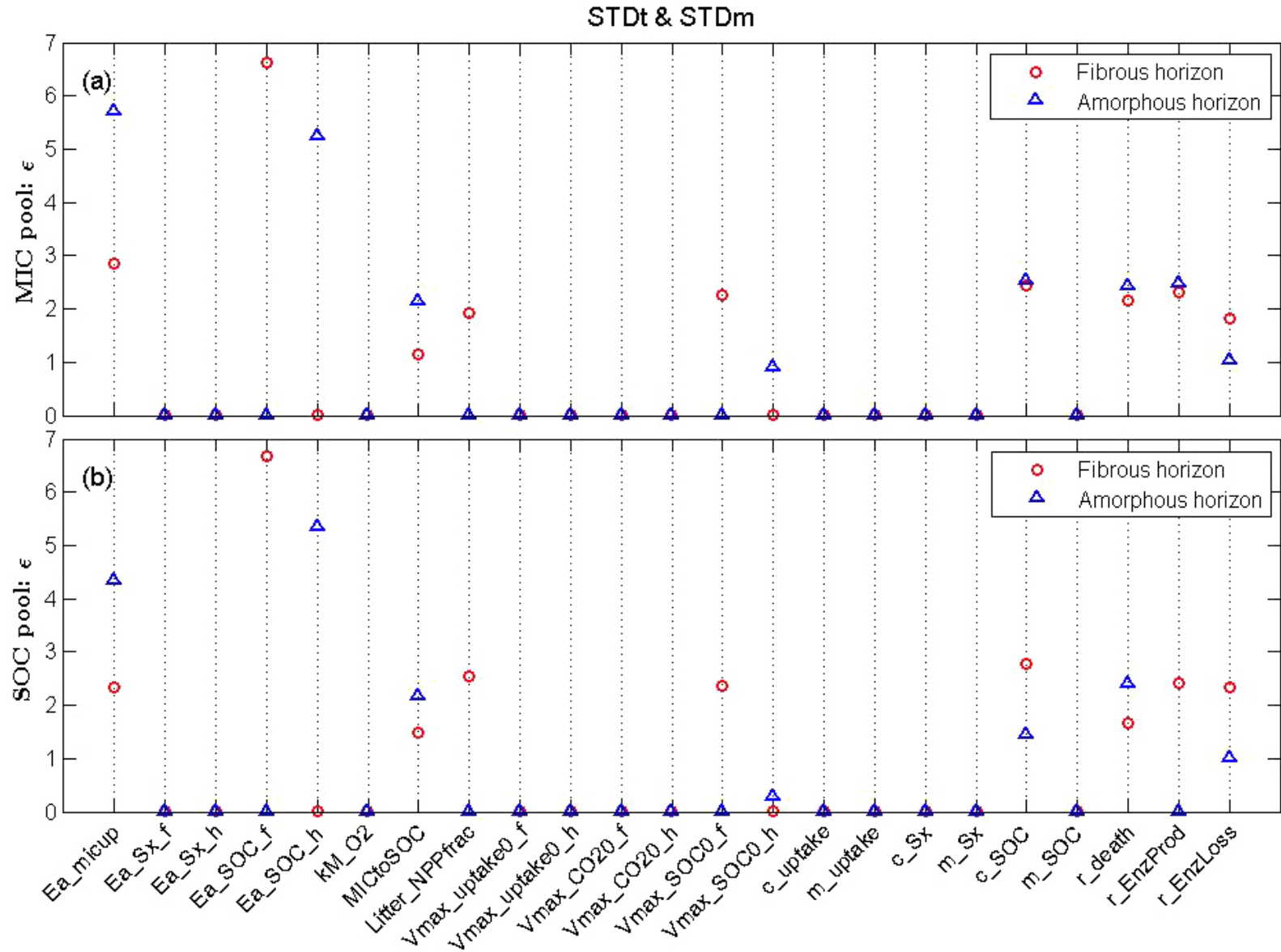

Figure 4. Screening test results (sensitivity index $\varepsilon=\sqrt{\mu_{\mathrm{EE}^{2}}^{*}+\sigma_{\mathrm{EE}^{2}}}$ ) for (a) microbial biomass C pool (MIC) and (b) soil organic C pool (SOC) under a standard soil temperature and moisture (STDt and STDm) scenario.

does not show a notably different response among parameters, while amorphous soil was most evidently responsive to microbial assimilation (Ea_micup) followed by the solubilization process (Ea_SOC_h) (Fig. 5a). Enzyme pool (ENZ) in general exhibited similar sensitivity patterns with that of MIC and SOC (Fig. 5b). These results indicate that microbial assimilation and substrate availability (solubilization process) are equally important factors for amorphous soil, while substrate availability superimposed over microbial assimilation are the most important controls of decomposition in fibrous soil.

Elevated temperature has overall greater effects on parameter sensitivity than altered moisture schemes and such effects are more pronounced in amorphous soil (Supplement Figs. S2-5). Elevated temperature reduced the sensitivity of activation energy parameters in microbial assimilation (Ea_micup) in both horizons, likely due to alleviated energy limitation in the microbial activity, which only further alleviated the constrain of substrate supply (decreased sensitivity to c_SOC) in amorphous soil MIC and SOC (Supplement Fig. S2). Temperature and moisture both have a notable ef- fect on SolubleC and ENZ in amorphous soil (Supplement Figs. S3-4). Similar to MIC and SOC in amorphous soil, elevated temperature alleviated energy limitation in microbial assimilation resulting in less sensitivity to Ea_micup. Raised soil moisture content with higher substrate diffusion likely increased the substrate supply (dissolved organic C) and thus further weakened the biochemical controls of microbial assimilation. This mechanism was also confirmed as responsible for the reduced sensitivity of SolubleC and ENZ to Ea_micup as the effects of increased temperature and moisture were offset by moisture limitation under the lowered moisture scheme (Et and Lm), rendering an increased sensitivity to activation energy-related parameters.

Through the Morris' elementary effect analysis, we selected 10 parameters (bolded in Table 2) out of the original 23 parameters for Sobol's sensitivity test to further investigate their importance.

\subsection{Sobol's sensitivity test}

A sufficiently large sample size was determined by a convergence test of sensitivity indices where sample size of 500, 

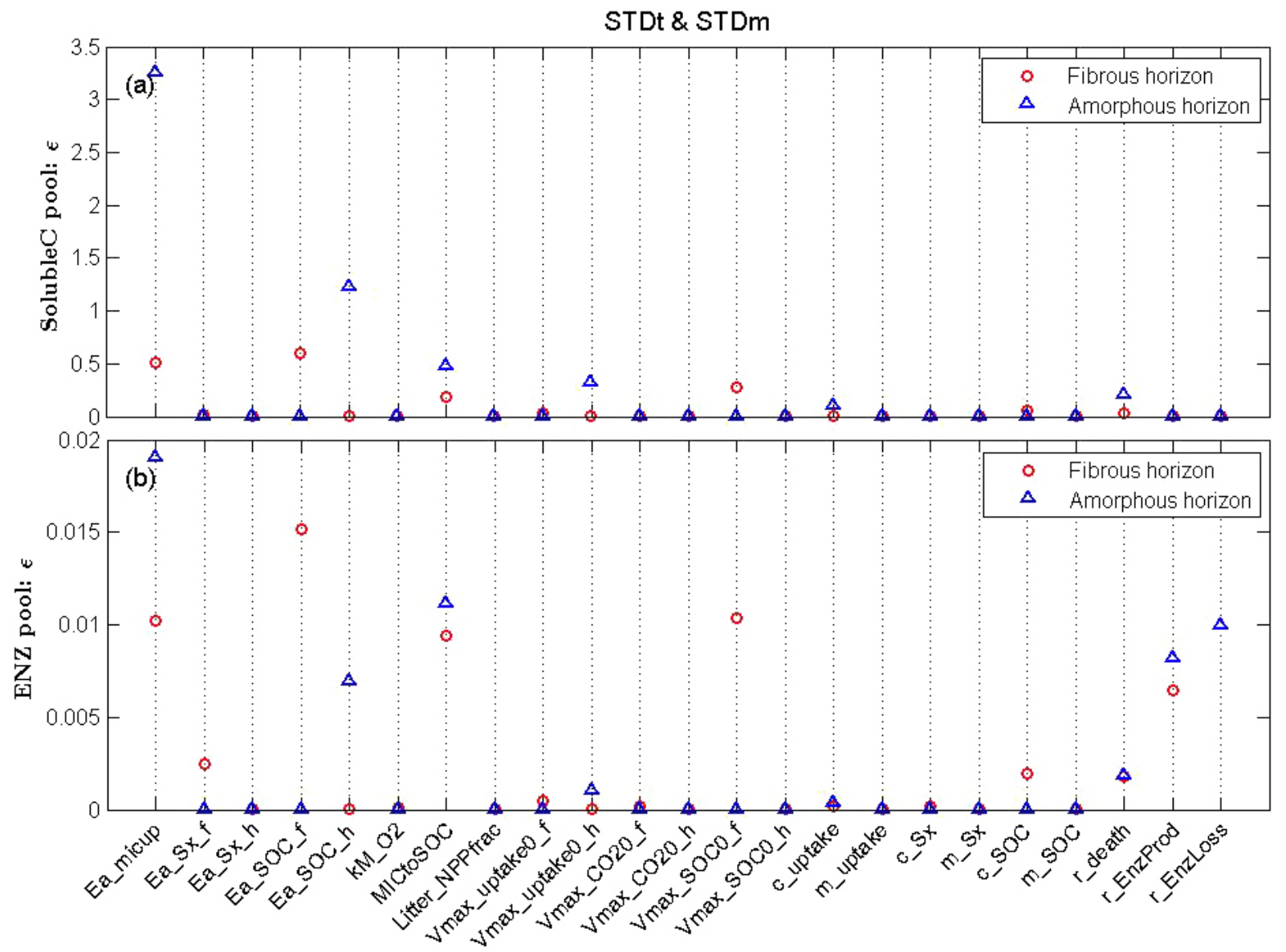

Figure 5. Screening test results (sensitivity index $\varepsilon=\sqrt{\mu_{\mathrm{EE}^{2}}^{*}+\sigma_{\mathrm{EE}}^{2}}$ ) for (a) soluble C pool (Soluble C) and (b) enzyme pool (ENZ) under a standard soil temperature and moisture (STDt and STDm) scenario.

1000, 2000, 4000, and 8000 were tested, respectively. The results showed that a sample size of 2000 produced similar indices to that of 4000 and 8000 and with narrower standard deviation compared with smaller sample sizes (Supplement Fig. S1). We therefore chose sample size of 2000 to conduct the Sobol's sensitivity test for the 10 parameters selected via the screening test. This corresponded to $2000 \times(10+2)=24000$ simulations.

\subsubsection{Decomposition in current environments}

In the fibrous horizon under standard temperature and moisture scenario, about $50-90 \%$ of the variability in the pool sizes of MIC, SOC, Soluble C, and ENZ can be explained by the uncertainty of Ea_micup, Ea_SOC_f, MICtoSOC, and enzyme turnover-related parameters, respectively (Fig. 6b). Slightly less than half of this variability $(20-40 \%)$ is attributed to first-order effects (Fig. 6a), while the rest was due to interactions with other parameters (Fig. 6b). c_SOC and enzyme kinetics-related parameters (r_EnzProf, r_EnzLoss) also explained about $10-40 \%$ of the variability of four pools in the fibrous horizon, with the interactive effects mostly ex- hibited in SOC and ENZ (first-order index less than half of total) (Fig. 6). These interactions indicate a tight coupling between soil $\mathrm{C}$ decomposition and microbial extracellular hydrolytic enzymes. In the amorphous horizon, the majority ( $>80 \%$ of total effect) of the variability in each pool can be attributed to parameters related to microbial activity and enzyme turnover (Ea_micup, MICtoSOC, r_EnzProd or r_EnzLoss) (Fig. 6b). Ea_micup, MICtoSOC, and r_death exerted half of their impacts on MIC and SOC via interactions with other parameters. Soluble $\mathrm{C}$ in amorphous soil was almost exclusively controlled by Ea_micup with the firstorder index responsible for about $70 \%$ of the pool size variability (Fig. 6a), while interactions with other parameters only added less than $5 \%$ (Fig. 6b), suggesting the paramount importance of microbial assimilation to the simulated soluble C pool size. ENZ pool was largely controlled by parameters related to enzyme turnover (r_EnzLoss and r_EnzProd) and soil enzymatic decay (Ea_SOC_f) with the majority of contribution coming from interactive effects (first-order index less than half of total). 


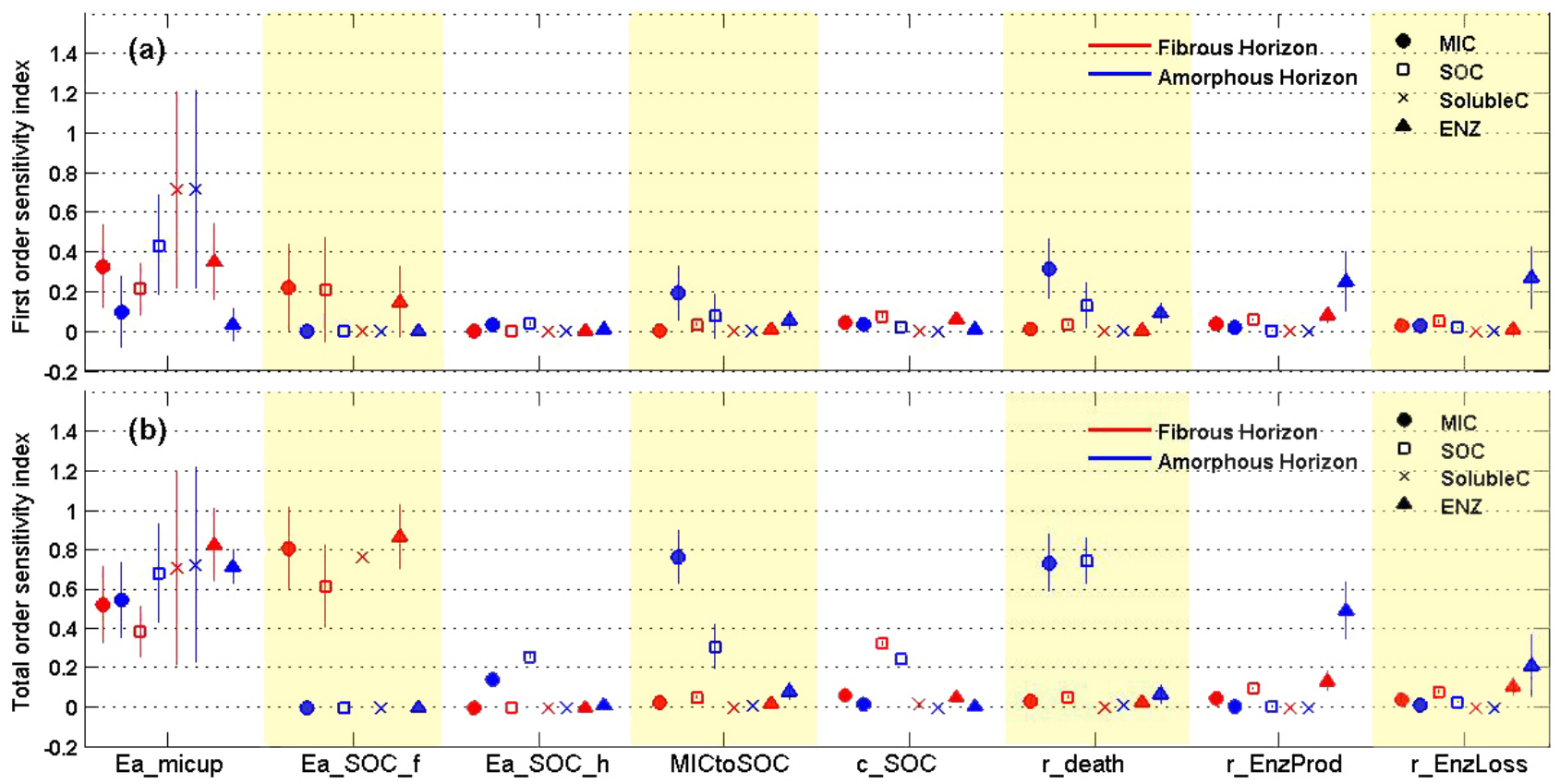

Figure 6. Sobol's estimates of first (a) and total-order (b) parameter sensitivity indices of microbial biomass (MIC), soil organic C (SOC), soluble C (SolubleC), and enzyme (ENZ) pools with their $95 \%$ confidence intervals (vertical lines) under standard soil temperature and moisture (STDt and STDm). 8 out of 10 selected parameters are presented here because the other 2 (Litter_NPPfrac and Vmax_SOC0_f) did not show significant sensitivity (sensitivity indices $<0.1$ ).
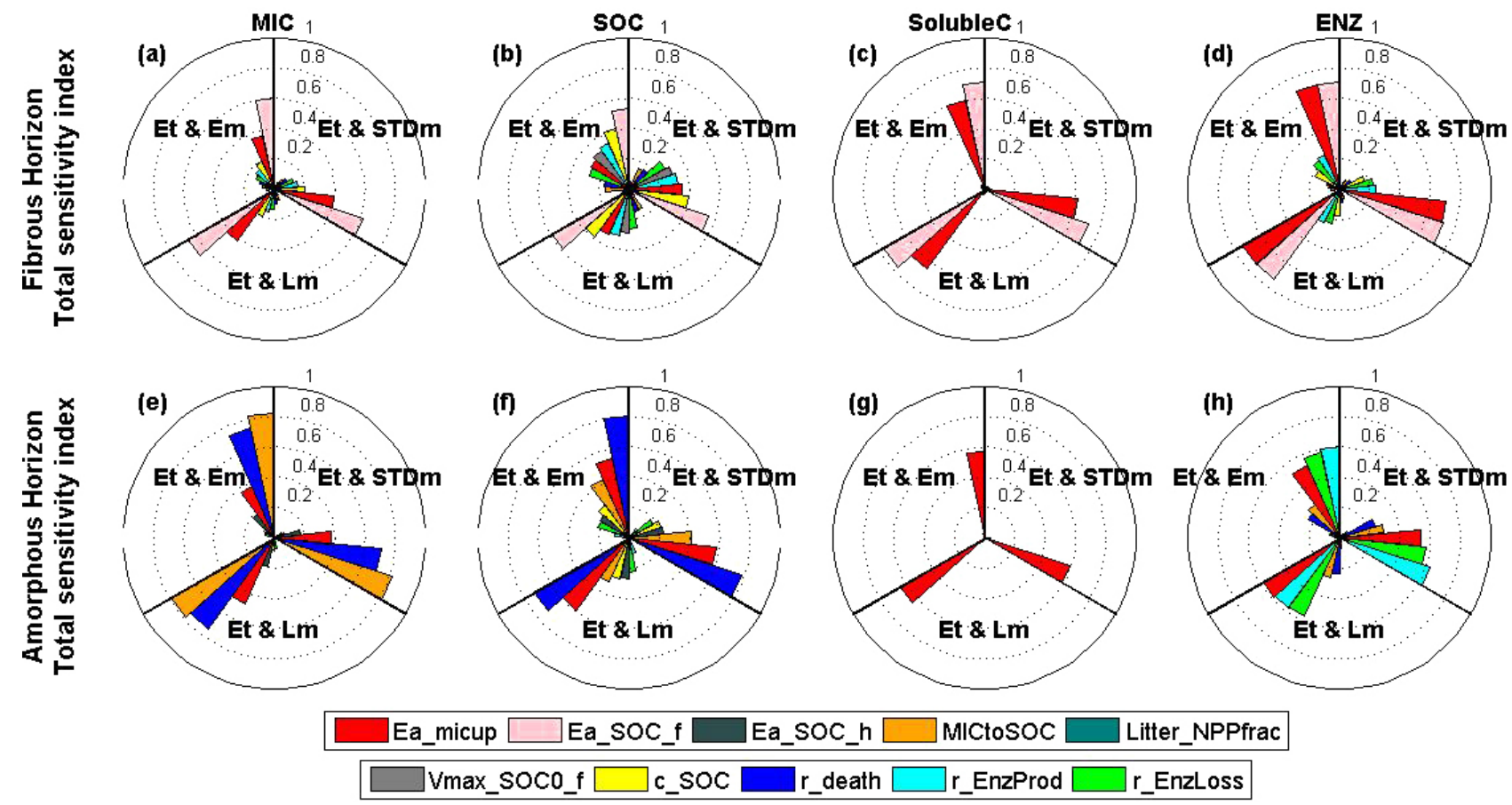

Figure 7. Coxcomb plot of Sobol's estimates of total-order parameter sensitivity indices for microbial biomass (MIC), soil organic C (SOC), soluble C (SolubleC), and enzyme (ENZ) pools under three altered environmental scenarios: elevated temperature and standard moisture (Et and STDm), elevated temperature and elevated moisture (Et and Em), elevated temperature and lowered moisture (Et and Lm) for fibrous horizon (first panel, a-d) and amorphous horizon (second panel, e-h). 


\subsubsection{Decomposition in altered environments}

The general pattern of sensitivity in fibrous and amorphous horizons is similar to that under the standard environment except for several distinctions in response to altered temperature and moisture level. MIC and SOC in the fibrous horizon was primarily controlled by solubilization with high sensitivity to Ea_SOC_f and c_SOC, followed by microbial assimilation (Ea_micup) (Fig. 7a, b), while the amorphous horizon was predominantly regulated by microbial dynamics-related processes (Ea_micup, MICtoSOC and r_death) (Fig. 7e, f). Temperature lowered the sensitivity of both horizons to activation energy terms but this effect was more notable in amorphous soil. Elevated temperature greatly reduced the sensitivity to energy threshold of microbial assimilation (Ea_micup) in the amorphous horizon by about $20 \%$ (from 0.7 in Fig. $6 \mathrm{~b}$ to 0.58 in Fig. 7f Et and STDm), while only about $10 \%$ in the fibrous horizon (from 0.38 in Fig. 6 b to 0.34 in Fig. $7 b$ ), indicating temperature associated energy limitation could be a major cause for low microbial activity in amorphous soil. Alleviated energy limitation likely results in greater MIC biomass and subsequently raises the sensitivity to microbial turnover (r_death, Fig. 7e,f). Altered moisture condition is expected to affect all 4 pools in the fibrous horizon, but only seems to have a slightly notable impact on Soluble $\mathrm{C}$ while other pools did not show a significant response (Fig. 7c). In contrast, raised moisture likely alleviated the moistureconstrained substrate supply in the amorphous horizon and favors microbial growth, the greater MIC biomass results in higher sensitivity of parameters associated with processes of microbial activity (e.g., r_death, MICtoSOC, Fig. 7e, f Et and STDm and Et and Em), while reduced moisture condition offset the temperature effect and yield in similar sensitivity level with that under standard environment (Fig. 7e, f Et and $\mathrm{Lm})$. The moisture response was overall less significant than the temperature effect with only marginal influence on parameter sensitivity (Fig. 7).

\section{Discussion}

\subsection{Different dominating process in fibrous and amorphous soils}

Environmental and biological factors exert different levels of control on amorphous and fibrous soils. Amorphous soil is predominantly controlled by microbial substrate assimilation (Figs. 4b, 6b), likely because the temperature induced energy limitation suppressed microbial activity. Increased moisture can alleviate the constraint to some extent, but microbial processes are still the primary controlling factors, inferred by the greater response of sensitivity to elevated temperature than to altered moisture (Fig. 7f). In fibrous soil, which is primarily limited by substrate supply and the solubilization process, increased moisture content does not have a significant effect on decomposition (Fig. 7b). This may partly be explained by the higher porosity (low water holding capacity) of fibrous soil. However, moisture effects in this model were only weakly captured in both horizons, indicating that key moisture control pathways may be missing in the model. For example, studies in a temperature forest ecosystem demonstrated that low soil moisture can strongly limit in situ enzyme activity in soils, compromising positive effects of warming (Steinweg et al., 2012). This moisture effect on enzyme activity was not represented in our model. The high sensitivity of the fibrous horizon to Ea_SOC_f indicates the enzyme-accessible substrate quality is an important factor of soil $\mathrm{C}$ decomposition in fibrous soil (Fig. 6b).

Many microorganisms produce exoenzymes that catalyze the breakdown of complex polymers to usable monomers (Ratledge, 1993). The importance of this enzyme kinetic process has been identified (Lawrence et al., 2009; Moorhead and Sinsabaugh, 2000) and proposed as a key mechanism for microbial C limitation due to low quality of soil or plantderived substrate (Schimel and Weintraub, 2003). The increased sensitivity of SOC enzymatic parameters under elevated temperature (Figs. 6b, 7b, f) is in line with the established kinetic theory and with laboratory incubations or field measurements (Lenton and Huntingford, 2003; Liski et al., 2003; Lloyd and Taylor, 1994; Sanderman et al., 2003), where the larger portion of SOC converted to soluble form under elevated temperature causes larger variation in the SOC pool. The apparent limited response of fibrous soil to moisture variation in this study is likely to be directly attributed to the model structure where SOC decay is not directly regulated by soil moisture content. Such formulation is based on the concern that exoenzymes are usually released on or near the reactive site of the enzyme and thus at the surface of substrate. In reality, reactions can continue even under relatively low soil moisture content because of exoenzymes (Lawrence et al., 2009). In contrast to the amorphous horizon for which external $\mathrm{C}$ input does not have a direct impact, the high sensitivity of fibrous SOC to the litterfall C input (sensitivity measure of SOC to litterfall $\mathrm{C}$ input in Sobol test is small due to smaller parameter range than in screening test) indicates the importance of site productivity (e.g., leaf area index) to fibrous decomposition (see a modeling experiment in Reichstein et al., 2003).

Our model sensitivity results suggest that while fibrous soil is dominated by extracellular enzymes catalyzing SOC decomposition, the microbial biomass' ability to use the breakdown products (microbial assimilation) appears to be the major controlling process in deeper amorphous horizons. Note here that the intrinsic microbial assimilation potential is prescribed to be the same in the two horizons (same Ea_micup). As the polymer breakdown and microbial assimilation of breakdown products can be disconnected (Schimel and Weintraub, 2003), such apparent sensitivity of the metabolic status of microbial community may mask the control of SOC enzymatic decay process and substrate 
availability. This suggests that despite the recalcitrant SOC (as prescribed in the parameters for amorphous soils), in contrast with the fibrous horizon, substrate supply is not the predominant factor limiting decomposition. Instead, temperature and moisture limitation on microbial and enzyme activity and the subsequently reduced microbial population size and metabolic activities are important in the decomposition of the amorphous horizon. Our results provide a mechanistic explanation that agrees favorably with the molecular study of permafrost soils in Alaska, which concludes that low microbial abundances and activities are likely to be the major limitations on decomposition rates (Waldrop et al., 2009). In addition to the low temperature sensitivity of microbial-related parameters, as also suggested by Waldrop et al. (2009), our sensitivity analysis identifies the high sensitivity of SOC decomposition to moisture conditions via the control on substrate availability (Waldrop and Harden, 2008). As microbial assimilation of DOC is directly regulated by the soil moisture content, reduced soil moisture could aggravate the limitation, making SOC decomposition even more sensitive to the microbial metabolism associated parameter (Ea_micup). Given the identified importance of microbial activities in amorphous soils and permafrost, changes in microbial composition and moisture condition may have a significant impact on soil $\mathrm{C}$ dynamics in boreal regions. As thawing permafrost alleviates diffusion constrains on substrate and hence enzyme activity, which concurrently enables growth of microbial biomass, permafrost degradation may generate greater SOC losses to the atmosphere (Schuur et al., 2008, 2009). The apparent response of microbial activity to moisture under thawing permafrost may also relieve the nutrient constraints on microbial assimilation, which although is not discussed in this study, may have implications for greater SOC loss via enhanced enzymatic decay (Mack et al., 2004; Schimel and Weintraub, 2003). Our modeling framework demonstrates the importance of microbial activity in amorphous soils underlain by permafrost. This mechanism is especially crucial in simulating soil $\mathrm{C}$ dynamics in boreal ecosystems where fire is a key component of ecosystem dynamics (Balshi et al., 2007, 2009; Kasischke and Turetsky, 2006), as post-fire reduction in microbial population size may reduce the potential of soil heterotrophs to decompose organic matter despite the warmer soil temperature in burned sites (Waldrop and Harden, 2008).

The apparent differences in sensitivity patterns between fibrous and amorphous soils should be explicitly represented in future modeling practices as soil organic matter is composed of different substrate pools exhibiting different sensitivities to environmental conditions (Conant et al., 2011; Hartley et al., 2007; Kirschbaum, 2004; Knorr et al., 2005). Such differentiation of soil substrate pools is critical in understanding long-term soil $\mathrm{C}$ dynamics, as soil components featured in long mean residence time (decades to centuries) comprise the majority of total soil C stocks (Conant et al., 2011). It is worth noting here that our results showed micro- bial turnover (r_death) and the fate of those residues (MICtoSOC) are among the most influential parameters. This conclusion aligns well with results from other microbial model analysis (e.g., Wieder et al., 2014) and suggests the potentially important role of these processes on soil organic matter stabilization (e.g., partitioning into physically vs. chemically protected SOC pools).

\subsection{Limitations and implications}

Our modeling framework accounts for the microbial activity and the enzymatic dynamics between SOC decomposition and the microbial physiology. However, it does not encompass several critical microbial physiological traits which may influence ecosystem-level $\mathrm{C}$ balance consequences. The freeze-thaw cycles that often occur in high-latitude permafrost regions may remobilize previously frozen DOC stocks and induce a pulse in microbial respiration (Hicks Pries et al., 2013; Schimel and Clein, 1996; Schuur et al., 2009; Vonk et al., 2013), reduce microbial biomass (Christiansen et al., 2012), and may also alter $\mathrm{N}$ mineralization which subsequently will have consequences on nutrient availability (Keuper et al., 2012; Schimel et al., 2007). Microbial community composition changes that may be induced by disturbance such as warming, fire, and soil freezethaw process may also result in impacts on soil $\mathrm{C}$ dynamics (Billings and Ballantyne, 2013). For example, changes in relative abundances of microbial functional groups may induce varying ability to compete for SOC and thus likely varying mass specific respiration rates, eventually leading to variation in soil respiration (Eliasson et al., 2005; Luo et al., 2001; Oechel et al., 2000). Shifts in microbial community structure could also alter the temperature sensitivity of decomposition (Bradford et al., 2008; Bradford et al., 2009). These complex feedback mechanisms are not included in the current model due to lack of sufficient theoretical understanding. Our results only weakly captured the effects of soil moisture on soil C mineralization as a driving variable, which can directly compromise the model's ability to reproduce spatial patterns in soil $\mathrm{C}$ dynamics, as soil moisture has been shown to be an important control on heterotrophic respiration at both regional and local scales (Brito et al., 2013; le Roux et al., 2013; Suseela et al., 2012). Incorporation of currently omitted processes and the improvement of mathematical representation in soil decomposition models may be needed. The fixed MIC/SOC and CUE in the objective function may have influenced the posterior parameters obtained. However, because this study focuses on sensitivity analysis in which we examined a relatively wide range for each parameter, our approach is appropriate in this context. Further studies should make use of time series of such information to help better constrain the model.

This study demonstrates how global sensitivity analysis can be used as a powerful tool to identify principal mechanisms of soil $\mathrm{C}$ dynamics under various soil and 
environmental conditions and highlights critical aspects of model structure and uncertainty. The sensitivity results are particularly relevant for model parameterization as they identify critical parameters that may have a large impact on model outputs (Cacuci et al., 2005). Such knowledge can potentially inform experimental practices about measurements that need to be taken and thus could be a power approach to guide datamodel integration. It is worthy to note here that for model applications in ecosystems other than the one presented in this study, differences in parameter ranges could result in different sensitivity results (Wallach and Genard, 1998). For example, we might expect moisture to have a less important role in SOC pool size variations in mesic systems than in arid ecosystems. Wallach and Genard (1998) recommend global sensitivity analysis for the detailed analysis of parameter space over the entire spectrum of plausible values. In this study, as most of the parameters (Table 2) are not well documented at the site level or biome/plant-functional-type level, we therefore chose to evaluate a plausible range based on current knowledge. For future model applications, more detailed optimization may be desired for accurately estimating model parameters from observations.

\section{Conclusions}

In this study, we presented a mechanistically based soil C dynamic model and evaluated the sensitivity of SOC decomposition to temperature and moisture effects in fibrous and amorphous soil horizons via a global sensitivity analysis. Our results showed that substrate availability, limited by both soil water diffusion and substrate quality, is a major constraint on SOC decomposition in the fibrous horizon, while energy limitation induced microbial activity is a primary control in amorphous soils. The tight coupling between soil organic matter mineralization and microbial extracellular hydrolytic enzymes is a critical process in both horizons. Elevated temperature alleviated the energy constraint of microbial activity most notable in amorphous soils, whereas moisture only exhibited a marginal effect on dissolved substrate supply and microbial activity. The apparent differences in sensitivity patterns between fibrous and amorphous soils in our results suggest that soils with different decomposition properties are controlled by different dominating processes. Soil decomposition models should consider explicitly representing different boreal soil horizons and soil-microbial interactions to better characterize biogeochemical processes in boreal forest ecosystems. A more comprehensive representation of critical biogeochemical mechanisms of soil moisture effects (e.g., plant root-soil interactions and freeze-thaw impact) may be required to improve the performance of the soil model we analyzed in this study.

\section{The Supplement related to this article is available online} at doi:10.5194/bg-11-4477-2014-supplement.
Acknowledgements. We acknowledge with gratitude the intellectual advice from Steven D. Allison, Eric A. Davidson, and Yingping Wang on various issues related to the study. This research is supported with a NSF project (DEB-0919331), the NSF Carbon and Water in the Earth program (NSF-0630319), the NASA Land Use and Land Cover Change program (NASA-NNX09AI26G), Department of Energy (DE-FG02-08ER64599), and the NSF Division of Information and Intelligent Systems (NSF-1028291). Support was also provided by Bonanza Creek Long-Term Ecological Research program (funded jointly by NSF the USDA Forest Service).

Edited by: M. Williams

\section{References}

ACIA: Impacts of a Warming Arctic-Arctic Climate Impact Assessment, in: ISBN 0521617782, Cambridge, UK: Cambridge University Press, December 2004, pp. 144, 2004.

Allison, S. D., Wallenstein, M. D., and Bradford, M. A.: Soil-carbon response to warming dependent on microbial physiology, Nat. Geosci., 3, 336-340, 2010.

Balshi, M. S., McGuire, A. D., Zhuang, Q., Melillo, J., Kicklighter, D. W., Kasischke, E., Wirth, C., Flannigan, M., Harden, J., Clein, J. S., Burnside, T. J., McAllister, J., Kurz, W. A., Apps, M., and Shvidenko, A.: The role of historical fire disturbance in the carbon dynamics of the pan-boreal region: A process-based analysis, J. Geophys. Res.-Biogeosci., 112, doi:10.1029/2006JG000380, 2007.

Balshi, M. S., McGuire, A. D., Duffy, P., Flannigan, M., Kicklighter, D. W., and Melillo, J.: Vulnerability of carbon storage in North American boreal forests to wildfires during the 21st century, Glob. Change Biol., 15, 1491-1510, 2009.

Beven, K.: A manifesto for the equifinality thesis, J. Hydrol., 320, 18-36, 2006.

Billings, S. A. and Ballantyne, F.: How interactions between microbial resource demands, soil organic matter stoichiometry, and substrate reactivity determine the direction and magnitude of soil respiratory responses to warming, Glob. Change Biol., 19, 90102, 2013.

Bonan, G. B., Lawrence, P. J., Oleson, K. W., Levis, S., Jung, M., Reichstein, M., Lawrence, D. M., and Swenson, S. C.: Improving canopy processes in the Community Land Model version 4 (CLM4) using global flux fields empirically inferred from FLUXNET data, J. Geophys. Res. Biogeosci., 116, G02014, doi:10.1029/2010JG001593, 2011.

Bond-Lamberty, B. and Thomson, A.: Temperature-associated increases in the global soil respiration record, Nature, 464, 579$582,2010$.

Bradford, M. A., Davies, C. A., Frey, S. D., Maddox, T. R., Melillo, J. M., Mohan, J. E., Reynolds, J. F., Treseder, K. K., and Wallenstein, M. D.: Thermal adaptation of soil microbial respiration to elevated temperature, Ecol. Lett., 11, 1316-1327, 2008.

Bradford, M. A., Watts, B. W., and Davies, C. A.: Thermal adaptation of heterotrophic soil respiration in laboratory microcosms, Glob. Change Biol., 16, 1576-1588, 2009.

Brito, P., Trujillo, J. L., Morales, D., Jiménez, M. S., and Wieser, G.: Soil moisture overshadows temperature control over soil $\mathrm{CO}_{2}$ 
efflux in a Pinus canariensis forest at treeline in Tenerife, Canary Islands, Acta Oecol., 48, 1-6, 2013.

Cacuci, D. G., Ionescu-Bujor, M., and Navon, I. M.: Sensitivity and uncertainty analysis, volume II: applications to large-scale systems, CRC Press, 2005.

Campolongo, F., Cariboni, J., and Saltelli, A.: An effective screening design for sensitivity analysis of large models, Environ. Modell. Soft., 22, 1509-1518, 2007.

Christiansen, C. T., Svendsen, S. H., Schmidt, N. M., and Michelsen, A.: High arctic heath soil respiration and biogeochemical dynamics during summer and autumn freeze-in - effects of long-term enhanced water and nutrient supply, Glob. Change Biol., 18, 3224-3236, 2012.

Conant, R. T., Ryan, M. G., Ågren, G. I., Birge, H. E., Davidson, E. A., Eliasson, P. E., Evans, S. E., Frey, S. D., Giardina, C. P., Hopkins, F. M., Hyvönen, R., Kirschbaum, M. U. F., Lavallee, J. M., Leifeld, J., Parton, W. J., Megan Steinweg, J., Wallenstein, M. D., Martin Wetterstedt, J. Å., and Bradford, M. A.: Temperature and soil organic matter decomposition rates - synthesis of current knowledge and a way forward, Glob. Change Biol., 17, 3392-3404, 2011.

Davidson, E. A. and Janssens, I. A.: Temperature sensitivity of soil carbon decomposition and feedbacks to climate change, Nature, 440, 165-173, 2006.

Davidson, E. A., Janssens, I. A., and Luo, Y.: On the variability of respiration in terrestrial ecosystems: moving beyond $Q_{10}$, Glob. Change Biol., 12, 154-164, 2005.

Davidson, E. A., Samanta, S., Caramori, S. S., and Savage, K.: The Dual Arrhenius and Michaelis-Menten kinetics model for decomposition of soil organic matter at hourly to seasonal time scales, Glob. Change Biol., 18, 371-384, 2012.

Duan, Q., Sorooshian, S., and Gupta, V.: Effective and efficient global optimization for conceptual rainfall-runoff models, Water Resour. Res., 28, 1015-1031, 1992.

Duan, Q., Sorooshian, S., and Gupta, V. K.: Optimal use of the SCEUA global optimization method for calibrating watershed models, J. Hydrol., 158, 265-284, 1994.

Eliasson, P. E., McMurtrie, R. E., Pepper, D. A., Strömgren, M., Linder, S., and Ågren, G. I.: The response of heterotrophic $\mathrm{CO}_{2}$ flux to soil warming, Glob. Change Biol., 11, 167-181, 2005.

Fan, Z, Neff, J. C., Harden, J. W., and Wickland, K. P.: Boreal soil carbon dynamics under a changing climate: A model inversion approach, J. Geophys. Res., 113, G04016, doi:10.1029/2006GL025677, 2008.

Frey, S. D., Lee, J., Melillo, J. M., and Six, J.: The temperature response of soil microbial efficiency and its feedback to climate, Nature Clim. Change, 3, 395-398, 2013.

Hartley, I. P., Heinemeyer, A., and Ineson, P.: Effects of three years of soil warming and shading on the rate of soil respiration: substrate availability and not thermal acclimation mediates observed response, Glob. Change Biol., 13, 1761-1770, 2007.

Hicks Pries, C. E., Schuur, E. A. G., and Crummer, K. G.: Thawing permafrost increases old soil and autotrophic respiration in tundra: Partitioning ecosystem respiration using $\delta^{13} \mathrm{C}$ and ${ }^{14} \mathrm{C}$, Glob. Change Biol., 19, 649-661, 2013.

Hugelius, G., Strauss, J., Zubrzycki, S., Harden, J. W., Schuur, E. A. G., Ping, C. L., Schirrmeister, L., Grosse, G., Michaelson, G. J., Koven, C. D., O’Donnell, J. A., Elberling, B., Mishra, U., Camill, P., Yu, Z., Palmtag, J., and Kuhry, P.: Improved estimates show large circumpolar stocks of permafrost carbon while quantifying substantial uncertainty ranges and identifying remaining data gaps, Biogeosciences Discuss., 11, 4771-4822, doi:10.5194/bgd-11-4771-2014, 2014.

Jorgenson, M. and Osterkamp, T.: Response of boreal ecosystems to varying modes of permafrost degradation, Canad. J. Forest Res., 35, 2100-2111, 2005.

Kasischke, E. S. and Turetsky, M. R.: Recent changes in the fire regime across the North American boreal region - Spatial and temporal patterns of burning across Canada and Alaska, Geophys. Res. Lett., 33, L09703, doi:10.1029/2008JG000723, 2006.

Keenan, T. F., Carbone, M. S., Reichstein, M., and Richardson, A D.: The model-data fusion pitfall: assuming certainty in an uncertain world, Oecologia, 167, 587-597, 2011.

Keuper, F., van Bodegom, P. M., Dorrepaal, E., Weedon, J. T., van Hal, J., van Logtestijn, R. S. P., and Aerts, R.: A frozen feast: thawing permafrost increases plant-available nitrogen in subarctic peatlands, Glob. Change Biol., 18, 1998-2007, 2012.

Kirschbaum, M. U. F.: Soil respiration under prolonged soil warming: are rate reductions caused by acclimation or substrate loss? Glob. Change Biol., 10, 1870-1877, 2004.

Knorr, W., Prentice, I. C., House, J. I., and Holland, E. A.: Longterm sensitivity of soil carbon turnover to warming, Nature, 433 , 298-301, 2005.

Lawrence, C. R., Neff, J. C., and Schimel, J. P.: Does adding microbial mechanisms of decomposition improve soil organic matter models?, acomparison of four models using data from a pulsed rewetting experiment, Soil Biol. Biochem., 41, 19231934, 2009.

Lenton, T. M. and Huntingford, C.: Global terrestrial carbon storage and uncertainties in its temperature sensitivity examined with a simple model, Glob. Change Biol., 9, 1333-1352, 2003.

le Roux, P. C., Aalto, J., and Luoto, M.: Soil moisture's underestimated role in climate change impact modelling in low-energy systems, Glob. Change Biol., 19, 2965-2975, 2013.

Liski, J., Nissinen, A., Erhard, M., and Taskinen, O.: Climatic effects on litter decomposition from arctic tundra to tropical rainforest, Glob. Change Biol., 9, 575-584, 2003.

Lloyd, J. and Taylor, J.: On the temperature dependence of soil respiration, Funct. Ecol., 1994. 315-323, 1994.

Luo, Y., Wan, S., Hui, D., and Wallace, L. L.: Acclimatization of soil respiration to warming in a tall grass prairie, Nature, 413, 622-625, 2001.

Mack, M. C., Schuur, E. A. G., Bret-Harte, M. S., Shaver, G. R., and Chapin, F. S.: Ecosystem carbon storage in arctic tundra reduced by long-term nutrient fertilization, Nature, 431, 440-443, 2004.

Mack, M. C., Treseder, K. K., Manies, K. L., Harden, J. W., Schuur, E. A. G., Vogel, J. G., Randerson, J. T., and Stuart Chapin III, F.: Recovery of aboveground plant biomass and productivity after fire in mesic and dry black spruce forests of interior Alaska, Ecosystems, 11, 209-225, 2008.

Manies, K. L., Harden, J. W., Yoshikawa, K., and Randerson, J.: The effect of soil drainage on fire and carbon cycling in central Alaska, US Geol. Surv. Profess. Paper, 1678, 145-152, 2003.

Manies, K. L., Harden, J. W., Silva, S. R., Briggs, P. H., and Schmid, B.: Soil data from Picea mariana stands near Delta Junction, Alaska of different ages and soil drainage type, US Geological Survey, 2004. 
Manzoni, S., Taylor, P., Richter, A., Porporato, A., and Ågren, G. I.: Environmental and stoichiometric controls on microbial carbonuse efficiency in soils, New Phytologist, 196, 79-91, 2012.

MathWorks Inc., MATLAB 2012a and Statistics Toolbox, Natick, Massachusetts, United States.

Medlyn, B. E., Robinson, A. P., Clement, R., and McMurtrie, R. E.: On the validation of models of forest $\mathrm{CO}_{2}$ exchange using eddy covariance data: some perils and pitfalls, Tree Physiol., 25, 839-857, 2005.

Moorhead, D. L. and Sinsabaugh, R. L.: Simulated patterns of litter decay predict patterns of extracellular enzyme activities, Appl. Soil Ecol., 14, 71-79, 2000.

Morris, M. D.: Factorial Sampling Plans for Preliminary Computational Experiments, Technometrics, 33, 161-174, 1991.

O'Donnell, J. A., Jorgenson, M. T., Harden, J. W., McGuire, A. D., Kanevskiy, M. Z., and Wickland, K. P.: The effects of permafrost thaw on soil hydrologic, thermal, and carbon dynamics in an Alaskan peatland, Ecosystems, 15, 213-229, 2012.

Oechel, W. C., Vourlitis, G. L., Hastings, S. J., Zulueta, R. C., Hinzman, L., and Kane, D.: Acclimation of ecosystem $\mathrm{CO}_{2}$ exchange in the Alaskan Arctic in response to decadal climate warming, Nature, 406, 978-981, 2000.

Pappas, C., Fatichi, S., Leuzinger, S., Wolf, A., and Burlando, P.: Sensitivity analysis of a process-based ecosystem model: Pinpointing parameterization and structural issues, J. Geophys. Res. Biogeosci., 118, 505-528, 2013.

Ratledge, C.: Biochemistry of microbial degradation, Kluwer Academic Publishers, 1993.

Reichstein, M., Rey, A., Freibauer, A., Tenhunen, J., Valentini, R., Banza, J., Casals, P., Cheng, Y., Grünzweig, J. M., and Irvine, J.: Modeling temporal and large-scale spatial variability of soil respiration from soil water availability, temperature and vegetation productivity indices, Global Biogeochem. Cy., 17, 2003.

Saltelli, A. and Scott, M.: Guest editorial: The role of sensitivity analysis in the corroboration of models and itslink to model structural and parametric uncertainty, Reliab. Engin. Syst. Saf., 57, 1-4, 1997.

Saltelli, A., Chan, K., and Scott, E. M.: Sensitivity analysis, Wiley New York, 2000a.

Saltelli, A., Tarantola, S., and Campolongo, F.: Sensitivity Analysis as an Ingredient of Modeling, Stat. Sci., 15, 377-395, 2000b.

Saltelli, A., Tarantola, S., Campolongo, F., and Ratto, M.: Sensitivity analysis in practice: a guide to assessing scientific models, Wiley, 2004.

Saltelli, A., Annoni, P., Azzini, I., Campolongo, F., Ratto, M., and Tarantola, S.: Variance based sensitivity analysis of model output. Design and estimator for the total sensitivity index, Computer Phys. Commun., 181, 259-270, 2010.

Sanderman, J., Amundson, R. G., and Baldocchi, D. D.: Application of eddy covariance measurements to the temperature dependence of soil organic matter mean residence time, Global Biogeochem. Cy., 17, doi:10.1029/2001GB001833, 2003.

Schimel, J. P. and Clein, J. S.: Microbial response to freeze-thaw cycles in tundra and taiga soils, Soil Biol. Biochem., 28, 10611066, 1996.

Schimel, J. P. and Weintraub, M. N.: The implications of exoenzyme activity on microbial carbon and nitrogen limitation in soil: a theoretical model, Soil Biol. Biochem., 35, 549-563, 2003.
Schimel, J. P., Balser, T. C., and Wallenstein, M.: Microbial stressresponse physiology and its implications for ecosystem function, Ecology, 88, 1386-1394, 2007.

Schmidt, M. W., Torn, M. S., Abiven, S., Dittmar, T., Guggenberger, G., Janssens, I. A., Kleber, M., Kögel-Knabner, I., Lehmann, J., and Manning, D. A.: Persistence of soil organic matter as an ecosystem property, Nature, 478, 49-56, 2011.

Schuur, E. A. G. and Trumbore, S. E.: Partitioning sources of soil respiration in boreal black spruce forest using radiocarbon, Glob. Change Biol., 12, 165-176, 2006.

Schuur, E. A. G., Bockheim, J., Canadell, J. G., Euskirchen, E., Field, C. B., Goryachkin, S. V., Hagemann, S., Kuhry, P., Lafleur, P. M., Lee, H., Mazhitova, G., Nelson, F. E., Rinke, A., Romanovsky, V. E., Shiklomanov, N., Tarnocai, C., Venevsky, S., Vogel, J. G., and Zimov, S. A.: Vulnerability of permafrost carbon to climate change: Implications for the global carbon cycle, Bioscience, 58, 701-714, 2008.

Schuur, E. A. G., Vogel, J. G., Crummer, K. G., Lee, H., Sickman, J. O., and Osterkamp, T. E.: The effect of permafrost thaw on old carbon release and net carbon exchange from tundra, Nature, 459, 556-559, 2009.

Sinsabaugh, R. L., Manzoni, S., Moorhead, D. L., and Richter, A.: Carbon use efficiency of microbial communities: stoichiometry, methodology and modelling, Ecol. Lett., 16, 930-939, 2013.

Sobol, I., Tarantola, S., Gatelli, D., Kucherenko, S., and Mauntz, W.: Estimating the approximation error when fixing unessential factors in global sensitivity analysis, Reliab. Engin. Syst. Saf., 92, 957-960, 2007.

Steele, S. J., Gower, S. T., Vogel, J. G., and Norman, J. M.: Root mass, net primary production and turnover in aspen, jack pine and black spruce forests in Saskatchewan and Manitoba, Canada, Tree Physiol., 17, 577-587, 1997.

Steinweg, J. M., Dukes, J. S., and Wallenstein, M. D.: Modeling the effects of temperature and moisture on soil enzyme activity: Linking laboratory assays to continuous field data, Soil Biol. Biochem., 55, 85-92, 2012.

Suseela, V., Conant, R. T., Wallenstein, M. D., and Dukes, J. S.: Effects of soil moisture on the temperature sensitivity of heterotrophic respiration vary seasonally in an old-field climate change experiment, Glob. Change Biol., 18, 336-348, 2012.

Tarnocai, C., Canadell, J. G., Schuur, E. A. G., Kuhry, P., Mazhitova, G., and Zimov, S.: Soil organic carbon pools in the northern circumpolar permafrost region, Global Biogeochem. Cy., 23, GB2023, doi:10.1029/2008GB003327, 2009.

Todd-Brown, K. E. O., Randerson, J. T., Post, W. M., Hoffman, F. M., Tarnocai, C., Schuur, E. A. G., and Allison, S. D.: Causes of variation in soil carbon simulations from CMIP5 Earth system models and comparison with observations, Biogeosciences, 10, 1717-1736, doi:10.5194/bg-10-1717-2013, 2013.

Vonk, J. E., Mann, P. J., Davydov, S., Davydova, A., Spencer, R. G. M., Schade, J., Sobczak, W. V., Zimov, N., Zimov, S., Bulygina, E., Eglinton, T. I., and Holmes, R. M.: High biolability of ancient permafrost carbon upon thaw, Geophys. Res. Lett., 40, 2689 2693, 2013.

Waldrop, M. P. and Harden, J. W.: Interactive effects of wildfire and permafrost on microbial communities and soil processes in an Alaskan black spruce forest, Glob. Change Biol., 14, 2591-2602, 2008. 
Waldrop, M. P., Wickland, K. P., White Iii, R., Berhe, A. A., Harden, J. W., and Romanovsky, V. E.: Molecular investigations into a globally important carbon pool: Permafrost-protected carbon in Alaskan soils, Glob. Change Biol., 16, 2543-2554, 2009.

Wallach, D. and Genard, M.: Effect of uncertainty in input and parameter values on model prediction error, Ecol. Modell., 105, 337-345, 1998.

Wang, C., Bond-Lamberty, B., and Gower, S. T.: Soil surface $\mathrm{CO}_{2}$ flux in a boreal black spruce fire chronosequence, J. Geophys. Res. Atmos., 107, WFX 5-1-WFX 5-8, 2002.

Wickland, K. P. and Neff, J. C.: Decomposition of soil organic matter from boreal black spruce forest: environmental and chemical controls, Biogeochemistry, 87, 29-47, 2008.

Wickland, K. P., Neff, J. C., and Harden, J. W.: The role of soil drainage class in carbon dioxide exchange and decomposition in boreal black spruce (Picea mariana) forest stands, Canad. J. Forest Res., 40, 2123-2134, 2010.

Wieder, W. R., Bonan, G. B., and Allison, S. D.: Global soil carbon projections are improved by modelling microbial processes, Nature Clim. Change, advance online publication, 2013.
Wieder, W. R., Grandy, A. S., Kallenbach, C. M., and Bonan, G. B.: Integrating microbial physiology and physio-chemical principles in soils with the MIcrobial-MIneral Carbon Stabilization (MIMICS) model, Biogeosciences, 11, 3899-3917, doi:10.5194/bg11-3899-2014, 2014.

Yarie, J.: Boreal forest ecosystem dynamics, I. anew spatial model, Canadian Journal of Forest Research-Revue Canadienne De Recherche Forestiere, 30, 998-1009, 2000.

Yi, S., Manies, K., Harden, J., and McGuire, A. D.: Characteristics of organic soil in black spruce forests: Implications for the application of land surface and ecosystem models in cold regions, Geophys. Res. Lett., 36, L05501, doi:10.1029/2008GL037014, 2009.

Yi, S., McGuire, A. D., Kasischke, E., Harden, J., Manies, K., Mack, M., and Turetsky, M.: A dynamic organic soil biogeochemical model for simulating the effects of wildfire on soil environmental conditions and carbon dynamics of black spruce forests, J. Geophys. Res., 115, G04015, doi:10.1029/2010JG001302, 2010. 